\title{
Medical Plants in Usadha: Loloh as Balinese Medicine and Traditional Herbal Product in Educational Perspective
}

\author{
I.W. Rasna ${ }^{1}$, D.K. Tantra ${ }^{2}$ \\ Faculty of Language and Arts \\ Universitas Pendidikan Ganesha \\ Singaraja, Bali \\ wayanrasna@ymail.com¹, dewatantra@yahoo.com²
}

\begin{abstract}
This research aims at conducting an investigation about medical plants written in Usadha manuscript (Balinese traditional healing text). The medical plants are ingredients for making herbal namely loloh. The sample was selected purposively from several sources. Usadha text about medical plants were analyzed by content analysis. The text data about Usadha was recorded from the traditional healers (balian) by using in-depth interviews. Data about potential consumers of the herbal medicine, loloh, were obtained from vocational school teachers and lecturers through questionnaire technique. Finding in this research is the enhancement of herbal loloh research not merely about the ingredients but also about the educational sight and the value of caring of the health of reproductive organs.
\end{abstract}

Keywords-loloh, medicine, herbal, education

\section{INTRODUCTION}

Traditional medical material is written in lontar usadha and has been used by balian's to cure various diseases (Tantra and Rasna, 2017: 106). They are used as 1) loloh (herbal drink), 2)boreh (powder), 3) tutuh (drop), 4) sumbuh (spurt), and 5) oles ( rub oil) [1], [2], [3], [4].

Since a long time ago, biodiversity has been used by our ancestors for medicine [5], [6]. However, the threat to natural resources caused by commercialization is much greater than that from the consumptive needs [7], [8]. This shows the little attention to medical plants [9]. This is confirmed in Trubus Infolet Herbal Indonesia Berkhasiat. It is said that there are ony nine special quality plants that have been clinically tested, namely: Indian bay leaf (Syzygium polyanthum), green chiretta (Andrographis paniculata), turmeric (Curcuma longa), red ginger zingiber (rubrum rhizoma), bay cedar (Guazuma ulmifolia), Java ginger (Curcuma zanthorrhiza), common guava (Psidium guajava), Javanese long pepper (Piper retrofractum Vahl), and cheese fruit (Morinda citrifolia).

Bali knowledge about the varieties of medical plants, and human health and fitness is written in palm leaves manuscript entitled Rukmini Tatwa. The content of Rukmini Tatwa comprises the benefits of some medical plants, especially for the health of the reproductive organs. Some benefits namely to improve the function of female intimate organ, to enhance the intercourse enjoyment, to look after the erectile capability of male intimate organ and also to improve the fertility. The knowledge of medical plants is becoming less known by people since the enthusiasm of learning and using the herbal medicine is also regressing day by day [4].

The simplicity of modern medicine causes a shift in popularity of the traditional medicines into the modern ones. This shift is caused by the regress of comprehending the palm leaves manuscript generally and sustaining the lexical of medicine plants [10], [11]. In other words, it can be said there is cultural erosion in Bali especially the knowledge about food plants and nutraceutical [12].

Indonesia is the second greatest country having various biodiversity after Brazil [13]. The existence of biodiversity as medicine has been known since thousands years ago [5].

Traditional healers use Usadha manuscripts as the reference for medical treatments. Lontar usadha consists of mantras, healing rituals, knowledge about leper especially the symptoms and the herbal ingredients used to cure it. Usadha Rare is written about some treatments for children. Usadha Kuranta Bolong contains the cure for babies and children. Usadha Carken Tingkeb contains types of medical plants; the content of Usadha Tua is about some diseases suffered by old people; Usadha Dalem contains treatments for internal disease; Taru Pramana is a knowledge about plants and the advantages; and Tutur Buta Kecapi contains about balian's ethics [14], [15]. Formerly medical plants were used based on experiences [16]. Serat Centhini (1814) is a text about everything concerning Javanese community life, including traditional medical system. The system that has educational aspects.

\section{METHODS}

The data collection is obtained by recording and interviewing some teachers at vocational schools and lecturers. Besides interview technique, some literary studies are involved including the eighteen palm manuscripts, lontar usadha. Several traditional healers including three from lecturers were also involved as informants. They were interviewed through in-depth interview technique. The texts 
about medical plants were analysed by using content analysis. There are three groups of data namely: interview text, questionnaires and writings.

The data about traditional healers were obtained through interviewing. The data about medical plants were obtained from literary studies. And the data about potential consumers of the herbal medicine, loloh, were obtained from vocational school teachers and lecturers through questionnaire technique.

\section{RESULTS AND DISCUSSION}

fruit (Monrendi citrifolia), 9) Betle leave (Piper betel) , 10) Star fruit ( Averrhoa carambola) , 11) Brown rice (Oriza sativa), 12) Cinnamon (Cinnamonmum zeylanicum), 13) Weedy rice (Oriza satival F. gulitinosa al auct), 14 Pennywort (Hydrocotle sibthorpisides lam), 15) Blumea (Blumea balsamifera DCF), 16) Chinese keys (Gasatrochilus panduratum ridl), 17) Indian fleabane (Pluchea Indica (L)

\subsection{Researches about loloh as Herbal Medicine \\ 3.1.1 Research about loloh as Medicine}

According to Tantra and Rasna [17] traditional drink in the form of loloh also serves also as medicine. Kinds of loloh namely 1) Greater galingage (Kaempferia galanga L.) 2) Wild ginger, temutis (Curcuma purpurascens Bl)., 3) Wild ginger, lempuyang (Zingiber zerumbet $(L)$ ), 4) Fruit bearing (Averrhoa bilimbi), 5) Blumea, Sambong (Blumea balsamifera D.C), 6) Ripening fruit, kacemcem (Spondias pinata kurz), 7) Turmeric (Curcuma domestica), 8) Cheese

Lees), 18) Sugar apples (Annona suquamosa L), 19) Garden shrub (Graptophullum pictum L., and 20) Cenfella (Cenfella asiatica $(L)$. The ingredients of loloh as herbal medicine are in Table I. The data are collected from traditional healers, those who are believed having ability to cure [18].

TABLE I. LIST OF MEDICAL PLANTS

\begin{tabular}{|c|c|c|c|c|c|c|}
\hline \multirow[t]{2}{*}{ No. } & \multirow{2}{*}{$\begin{array}{l}\text { Name of medical } \\
\text { plants }\end{array}$} & \multirow[t]{2}{*}{ Scientific Name } & \multirow{2}{*}{$\begin{array}{l}\text { Useful parts of } \\
\text { plant }\end{array}$} & \multicolumn{2}{|c|}{$\begin{array}{c}\text { Indications } \\
\text { (according to informants) }\end{array}$} & \multirow[t]{2}{*}{ Composition } \\
\hline & & & & Usadha & $\begin{array}{l}\text { Traditional } \\
\text { Healers }\end{array}$ & \\
\hline 1. & Greater galingage & Kaemferia galanga $L$. & Tuber/root & $\begin{array}{l}\text { cough, rheumatism, } \\
\text { itchy skin, babies' } \\
\text { stomach ache }\end{array}$ & $\begin{array}{l}\text { cough, rheumatism, itchy } \\
\text { skin, stomach ache }\end{array}$ & $\begin{array}{l}\text { Volatile oil with the } \\
\text { components: } \\
\text { Etil, } \\
\text { metoksisinamat, } \\
\text { etilsinamat, borneol, } \\
\text { karbon }\end{array}$ \\
\hline 2. & Wild ginger Temutis & $\begin{array}{l}\text { Curcuma } \\
\text { purpurascens } B l\end{array}$ & Tuber & $\begin{array}{l}\text { joints swelling, difficulty } \\
\text { urinating, cough, hard } \\
\text { breathing in children, } \\
\text { diarrhoea containing bloo }\end{array}$ & $\begin{array}{l}\text { joints swelling, difficulty } \\
\text { in urinating, cough, hard } \\
\text { breathing }\end{array}$ & $\begin{array}{l}\text { Volatile oil, } \\
\text { champor, bereol } \\
\text { (Suryadarma (2010: } \\
301 \text { ) }\end{array}$ \\
\hline 3. & $\begin{array}{l}\text { Wild ginger, } \\
\text { Gamongan }\end{array}$ & $\begin{array}{l}\text { Zingerber } \\
\text { aromaticum vall }\end{array}$ & Tuber & $\begin{array}{l}\text { pain in the right part of } \\
\text { stomach, drop in } \\
\text { consciousness, swelling } \\
\text { in legs, asthma, anemia }\end{array}$ & $\begin{array}{l}\text { pain in the right part of } \\
\text { stomach, drop in } \\
\text { consciousness, swelling in } \\
\text { legs, asthma, }\end{array}$ & $\begin{array}{l}\text { Volatile oil, limonen } \\
\text { and zirumen } \\
\text { (Suryadarma, 2010: } \\
\text { 301) }\end{array}$ \\
\hline 4. & Fruit bearing & Averrho belimbi L & $\begin{array}{l}\text { Flower, root, } \\
\text { leave }\end{array}$ & heatiness, reddish faeces & heatiness, reddish faeces & 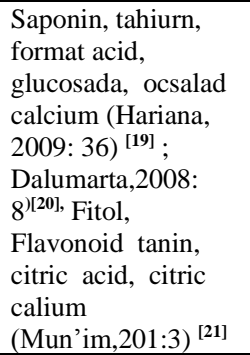 \\
\hline 5. & Blumea, Sambong & $\begin{array}{l}\text { Blumea balsami fera } \\
\text { D.C }\end{array}$ & Leave & $\begin{array}{l}\text { urine problem } \\
\text { (containing blood and } \\
\text { pus) (Tengah,1995: 638) }\end{array}$ & $\begin{array}{l}\text { urine problem (containing } \\
\text { blood and pus) }\end{array}$ & $\begin{array}{l}\text { Bormeol, cineol, } \\
\text { meal, eter, } \\
\text { palmitinacid, } \\
(\text { Septian, 2009: } \\
232)^{22]}\end{array}$ \\
\hline 6. & $\begin{array}{l}\text { Ripening fruit, } \\
\text { Cemcem }\end{array}$ & Spondia pinata kur & Leave, skin & $\begin{array}{l}\text { goiter, } \\
\text { Diabetes }\end{array}$ & goiter & -- \\
\hline 7. & Turmeric, Kunyit & Curceema domistica & Tuber & $\begin{array}{l}\text { fever, flu, rhematics, } \\
\text { diarehea }\end{array}$ & fever, flu, rheumatic & $\begin{array}{l}\text { Water, calorie, } \\
\text { carbohydrate, } \\
\text { protein, calcium, } \\
\text { phosphorus, } \\
\text { vitamins A<B,C, } \\
\text { volatile oil, } \\
\text { curcumin (Sejati, } \\
2003)^{[23]}\end{array}$ \\
\hline
\end{tabular}




\begin{tabular}{|c|c|c|c|c|c|c|}
\hline 8. & Cheese fruit & Morindi citrifolia & Fruit, root & fever, lack of appetite & fever, lack of appetite & $\begin{array}{l}\text { Root: Cepronacind, } \\
\text { Carsilat acid, } \\
\text { morindi, Leaf: } \\
\text { protein, lime, iron, } \\
\text { carotin ( Hariana, } \\
\text { 2009) }\end{array}$ \\
\hline 9. & $\begin{array}{l}\text { Betle leave, } \\
\text { Base }\end{array}$ & Piper betle $L$ & Leaf & $\begin{array}{l}\text { womb refresher, curing } \\
\text { cough }\end{array}$ & $\begin{array}{l}\text { womb refresher, curing } \\
\text { cough }\end{array}$ & $\begin{array}{l}\text { Volatile oil, cavical, } \\
\text { carvocal, (Nuraimi, } \\
2014^{[24]} \text {, Elshabrana, } \\
2013^{[25]} \text { ) }\end{array}$ \\
\hline 10. & $\begin{array}{l}\text { Star fruit, } \\
\text { Belimbing }\end{array}$ & Avverhoa carambola & Leaf, stem & $\begin{array}{l}\text { absces, goiter, } \\
\text { urinary problem } \\
\text { stomach ache }\end{array}$ & $\begin{array}{l}\text { absces,goiter, urinary } \\
\text { problem, stomach ache }\end{array}$ & $\begin{array}{l}\text { Tanin, sufur, format } \\
\text { acid, calcium } \\
\text { ocsalat, (Nuraini, } \\
\text { 2014: } 16-170 \\
\end{array}$ \\
\hline 11. & $\begin{array}{l}\text { Brown rice, } \\
\text { Baas Barak }\end{array}$ & Oriza sativa linn.F & Fruit & $\begin{array}{l}\text { lack of appetite, dry } \\
\text { lips, diarhea, painful } \\
\text { stomach, diarhea and } \\
\text { bleeding, diabetes }\end{array}$ & $\begin{array}{l}\text { lack of appetite, dry lips, } \\
\text { diarhea, painful stomach, } \\
\text { diarhea and bleeding, } \\
\text { diabetes }\end{array}$ & $\begin{array}{l}\text { Carbohydrate, } \\
\text { protein, tiamin, low } \\
\text { glicemic inde amino } \\
\text { acid, iron, selenium } \\
\text { fiber, vitamins B 6, } \\
\text { phytochemical } \\
\text { fenolat magnesium } \\
\text { (Khalil, 2016: 49) } \\
\text { [26] }\end{array}$ \\
\hline 12. & $\begin{array}{l}\text { Cinnamon, } \\
\text { Kayu manis }\end{array}$ & $\begin{array}{l}\text { Cinnamomun } \\
\text { Zeylanicum Ness }\end{array}$ & Tree, leaf & $\begin{array}{l}\text { white mouth, dirty } \\
\text { condition and infection, } \\
\text { gout, stomach ulcer, } \\
\text { gastric problem }\end{array}$ & $\begin{array}{l}\text { white mouth, dirty } \\
\text { condition and infection, } \\
\text { gout, hernia, stomach } \\
\text { inflammation, gastric } \\
\text { problem }\end{array}$ & $\begin{array}{l}\text { Volatile oil, tanin, } \\
\text { resin, (Putra, 2014: } \\
\text { 155) Sinamaldehid } \\
60-75 \% \text {, sinamil } \\
\text { acetat, cugenol 1-5^, } \\
\text { betha carotine } 1- \\
4 \%, \text { linalso } 1-35 \\
\text { (Mun'in, 2011;83) }\end{array}$ \\
\hline 13. & $\begin{array}{l}\text { Weedy rice, } \\
\text { Ketan gajih }\end{array}$ & $\begin{array}{l}\text { Oriza satvival } F . \\
\text { Glutinosa alba Auct }\end{array}$ & Grain & $\begin{array}{l}\text { baby stomach disorder, } \\
\text { suffering from intestinal } \\
\text { worms } \\
\text { lack of appetite, high } \\
\text { fever, restlessness }\end{array}$ & $\begin{array}{l}\text { baby stomach disorder, } \\
\text { suffering from intestinal } \\
\text { worms } \\
\text { lack of appetite, high } \\
\text { fever, restlessness }\end{array}$ & $\begin{array}{l}\text { Protein } 7.0 \mathrm{~g}, \text { fat, } \\
0.7 \mathrm{t}, \\
\text { carbohydrate, } 78.0 \mathrm{~g} \text {, } \\
\text { calsium } 10.0 \mathrm{mg}, \\
\text { fosfor, } 148.0 \mathrm{mg}, \\
\text { iron, } 0.8 \mathrm{mg}, \\
\text { vitamin B1 } 0.2 \mathrm{mg} \\
\text { and water } 13.0 \mathrm{mg} \\
\text { (Khalil, } 2016: 93 \text { ) }\end{array}$ \\
\hline 14. & $\begin{array}{l}\text { Pennywort, } \\
\text { Sumanggigunung }\end{array}$ & $\begin{array}{l}\text { Hydrocotyle } \\
\text { sibthrpioides lain }\end{array}$ & Leaf, stem root & cough with bleeding & cough with bleeding & $\begin{array}{l}\text { coumarin, hiperin } \\
\text { (Damartha, 2008: } \\
\text { 159-160 BS geuBm } \\
\text { 1\2013: } 327 \text { ) }\end{array}$ \\
\hline 15. & $\begin{array}{l}\text { Blumea, } \\
\text { Sembunggantung }\end{array}$ & $\begin{array}{l}\text { Blumea Basamifera } \\
\text { DCF }\end{array}$ & Leaf & intestinal worms & intestinal worms & - \\
\hline 16. & $\begin{array}{l}\text { Chinese keys, } \\
\text { Teти Kunci }\end{array}$ & $\begin{array}{l}\text { Gastrochilus } \\
\text { panduraum Ridl }\end{array}$ & Tuber & $\begin{array}{l}\text { dry cough, oral } \\
\text { ulceration, urine } \\
\text { problem, ringworm, } \\
\text { gallstone, painful penis }\end{array}$ & $\begin{array}{l}\text { dry cough, oral ulceration, } \\
\text { urine problem, ringworm, } \\
\text { gallstone, painful penis }\end{array}$ & $\begin{array}{l}\text { Sineol, champho } \\
\text { r, d-orneol d- pinen, } \\
\text { sisquin torpen, } \\
\text { zingiboon } \\
\text { curcumien, } \\
\text { zedoarin, amilum, } \\
\text { resin ) Tengah, } \\
\text { 1995: 688-689) [26] }\end{array}$ \\
\hline 17. & $\begin{array}{l}\text { Indian fleabane, } \\
\text { Bluntas }\end{array}$ & $\begin{array}{l}\text { Pluchea Indicia }(L) \\
\text { Lees }\end{array}$ & Leaf & $\begin{array}{l}\text { lack of appetite, } \\
\text { digestive problem, fever, } \\
\text { cough, difficult } \\
\text { breathing }\end{array}$ & $\begin{array}{l}\text { lack of appetite, digestive } \\
\text { problem, reducing fever, } \\
\text { cough, difficult breathing }\end{array}$ & $\begin{array}{l}\text { Alkaloid, volatile } \\
\text { oil, quercetine, } \\
\text { saponin, propofenol, } \\
\text { flavonid, alkaloid } \\
\text { (Untung, Trubus, } \\
\text { n.d: 216) [28] }\end{array}$ \\
\hline 18. & $\begin{array}{l}\text { Garden shrub, } \\
\text { Temen }\end{array}$ & $\begin{array}{l}\text { Graptophllum Pictum } \\
L\end{array}$ & Leave & Cough, flu & Cough, flu & - \\
\hline 19. & Sugar apples & Annona suquamosa $L$ & Fruit, leave & Abses, dog worms & Abses, dog worms & $\begin{array}{l}\text { Borneal, comphor, } \\
\text { terpene alkaloed } \\
\text { anonam im roost } \\
\text { and bark. The } \\
\text { seeds contain fat, } \\
\text { resin. The fruit } \\
\text { contains amino acid } \\
\text { and tannin }\end{array}$ \\
\hline
\end{tabular}




\begin{tabular}{|c|c|c|c|c|c|c|}
\hline & & & & & & $\begin{array}{l}\text { (Hariana,2013; 358- } \\
\text { 359) }\end{array}$ \\
\hline 20. & Cenfella, Peduh & Cenfella asitica $(L)$ & Leave & Reducing fever & Reducing fever & $\begin{array}{l}\text { Asiaticoside, } \\
\text { Thnkunside } \\
\text { medicassoside/bfah } \\
\text { mocide madasiatic } \\
\text { acie (Hariana, } \\
\text { 2018:274) }\end{array}$ \\
\hline
\end{tabular}

\subsubsection{Research on Loloh as Balinese Traditional Drink}

The ingredients for this Balinese traditonal herbal drink are found in lontar usadha that describes the medical plants [29], [30], [31]. Traditional food is consumed by certain ethnic communities [32]. Traditional food has the competitive advantage that is natural, rich in taste and available all year long [33]. The weakness is the unattractive presentation, local taste, nonstandard mixture [34]. Apart from this, industry drink products monopolize local, national and international markets [35]. We are very aware that the drinks

by alcohol. The ex-President of France said that our greatest enemy is alchoholic drink. It will cause us a greater problem than the battle against German [36]. In the light of these problems, it is time for moving from alcohol consumers to traditional drinks, except tuak, and arak, as traditional drink can increase the community economy [36], [37], [38]. If the traditional drink is presented in a modern presentation, laboratory testing, so that it meets health requirements, it will bring benefit for holding capacity of tourism development and creative economy through local culinary since tourism sector needs support from natural food and drink providers [39].

Medical plants can function as medicine and herbal beverages, for example kencur to cure cough, rheumatism, itchy skin, disease suffered by babies. In addition, it can also be used as herbal treatments such as jamu beras kencur. Similarly, wild ginger, temutis as to cure swelling, mix with red ginger to serve as herbal drink. Cheese fruit can cure fever, lack of appetite. In addition, it can be used as a herbal drink. This happens because the plants serve as medicine [16]. The use of natural substances as traditional medicine in Indonesia has been done by our ancestors [40]. The use is related to the historical background of Bali community life [41]. The background is that Balinese were farmers, the people were close to agricultural crops like ginger, turmeric, rice and galingale, wild ginger temu lawak, which are traditional drink ingredients. The use of herbal drink is part of the nation's culture [42], both as a drink and a medicine. The basic ingredients of jamu (traditional herbal drink) are ginger, turmeric, wild ginger temulawak and galingale which are usually used as traditional medicines, since the effectiveness of the spices that is related to antioxidant in ginger [43], turmeric as anti-rheumatic [44], temulawak as anti-hepatitis [45], [46], [47]. Out of all kinds of loloh (herbal drink), not all have commercial potential because of their tastes. Those that have the commercial potential are galingale, temutis (Curcuma Purpurascens), cemcem (Spondias Pinata Kurz), mengkudu ( Morindi sold in the market contain much alcohol which is consumed not only by young people, but also by below young children , old people, celebrities, political elite [36].

In U.K. scholars stated that $95 \%$ of mental cases were caused by alchoholic drinks. French Health Minister said that the mortality rate caused by alcohol is 20.000 people each year. Secretary General of the Committee for Alcohol Eradication stated that $25 \%$ of the industrial accidents and $57 \%$ of highway accidents were caused

Cirifolia), brown rice (Oriza sativa linn.F), beluntas Pluechea Indica (L) Lees) and turmeric.

\subsubsection{Medical Plants in Educational Perspective}

The use of medical plants to be loloh are not only about the advantage of herbal medicine but also about the health education. In this case, the educational perspective has its role. Loloh is useful as herbal treatments which usages, ingredients and dosages have to be learned. Meanwhile the plants have to be available during the necessary time. It means that the plants have to be cultivated. It should be learned how to seed, to plant, to look after, and to harvest the plants especially how to choose the best harvesting time that is related to the quality of the crops.

People also would like to know the names of those medicine plants. The names and the description are studied by using Ecolinguistics approach.

The customs of cunsuming loloh is one of some efforts to grow the caring of local culture and natural products. The next educational perspective is that by maintaining the customs of consumming loloh, people tend to be economists, especially in saving expenses for buying any other supplements or chemical medicine.

The customs of consuming loloh can emerge the curiousity of mantaining, and preserving both the medical plants and the planting areas. The younger generations by the help from their seniors would learn more about loloh. Especially, children would learn about the kinds of medical plant and the plants' characteristics. This learning is related to ecolinguistics.

The knowledge of medical plants cultivation has ecopedagogical, ecological, and ecolinguistical practices. Moreover, the cultivation of medical plants can coincidentally grow the eco-tourism since there should be a parralel process of cultivating and producing the herbals, which are actually kinds of attraction.

The next educational aspect is the area of medical plants cultivation can be a natural laboratorium for students to learn many disciplines, among them, the etnofarmachology, ecolinguistics, and etnobothany. 


\section{CONCLUSION AND SUGGESTION}

1. The research about the ingredients of loloh as medicine comes from usadha balian and the contents of its main ingredients scientifically has a logical relation. The main ingredients of the medicine are Greater galingage (Kaempferia galanga L.) Wild ginger, temutis (Curcuma purpurascens $B l$ )., Wild ginger, lempuyang (Zingiber zerumbet $(L)$ ), Fruit bearing (Averrhoa bilimbi), Sambong (Blumea balsamifera D.C), Ripening fruit, kacemcem (Spondias pinata kurz), Turmeric (Curcuma domestica), Cheese fruit (Monrendi citrifolia), Betle leave (Piper betel), Starfruit (Averrhoa carambola), Brown rice (Oriza sativa), Cinnamon (Cinnamonmum zeylanicum), Weedy rice (Oriza satival F. gulitinosa al auct), Pennywort (Hydrocotle sibthorpisides lam), Blumea (Blumea balsamifera DCF), Chinese keys (Gasatrochilus panduratum ridl), Indian fleabane (Pluchea Indica (L) Lees), Sugar apples (Annona suquamosa L), Garden shrub (Graptophullum pictum L., and Cenfella (Cenfella $\operatorname{asiatica}(L)$.

2. The research of loloh as Balinese traditional herbal drink shows that it has the strength because it is natural, useful as medicine and has the economic potential. The herbal plants in this category are galangal, wild ginger, temutis, ripening fruit, turmeric, cheese fruit, brown rice, chinese keys, and blumea.

3. Medical plants have the educational perspectivees specifically it encourages an interdisciplinary studies, namely, ecology, eco-pedagogy, ethno-pedagogy, ethnobotany, eco linguistics, and ethno-pharmacology. Besides the cultivation of medical plants emerges the development of ecotourism.

\section{REFERENCES}

[1] Tantra, Dewa Komang and Rasna Wayan, 2017. Diversifikasi Tanaman Herbal Menjadi Produk Minuman untuk Masyarakat Lokal dan Wisatawan in Jurnal Kajian Bali Volume 07, Nomor 01 April 2017.Denpasar: Pusat Kajian Bali Universitas Udayana.

[2] Sujana, et al. 2004. Pengembangan Ekonomi Kreatif Berbasis Warga Belajar dalam Mendukung Kepariwisataan di Bali.Laporan Penelitian MP3Iundiksha Unpublished.

[3] Sukarsa,I MSW.2004. Sisi Ekonomi Sevbuah Upacara dalam Proseding Seminar Konservasi Tumbuhan Upacara Agama Hindu. Candikuning: Bagian Proyek Pelestarian,Penelitian dan Pengembangan Flora Kawasan Timur Indonesia UPT Bali Konserasi Tumbuhan Kebun Raya Eka Karya Bali - LIPI

[4] Suryadarma, IGP. 2010. Keanekaragaman Tumbuhan Bahan Kebugaran dalam Naskah Lontar Rukmini Tatwa Massyarakat Bali in Jurnal Biota Vol 15 (2) 294 - 305

[5] Hanum Siti F. 2006. Reinventarisasi dan Eksplorasi Tumbuhan Usadha Bali: 3 Kecamatan Klungkung, Kabupaten Klungkung dalam Laporan Teknik Program Perlindungan dan Konservasi Sumber Daya Alam Kebun Raya Eka Karya Bali.

[6] Sukarti, I Gusti Ayu, 1987, Tanaman Obat dalam Lontar Usadha. Bali: Proyek Pengadaan Pengembangan dan Pengawasan Obat dan Makanan Dinas Kesehatan Provinsi Bali

[7] Komar, T.E. 2003. Pelestarian dan Pemafaatan Keanekaragaman Flora. Prosiding Ekspose Hasil- Hasil Penelitian: Pemanfaatan Jasa
Hutan dan Nonkayu Berbasis Masyarakat sebagai Solusi Peningkatan Produtivitas dan Pelestarian Hutan. Cisarua 12 Desember 2003.Bogor :Puslitbang Huan dan Konservasi Alam.

[8] Mahayani, Dewi. 2010. Eksplorasi Pemanfaatan dan Budi Daya Kayu Songga seagai Bahan Obat Alternatif di Provinsi NTB dan Bali: Mataram :Balitbang Kehutanan

[9] Rasna and Binawati. 2013. Pengetahuan Tanaman Obat Tradisional untuk Penyakit Anak Pada Komunitas Remaja di Bali in Jurnal Bumi Lestari Volume 13 Nomor 1 Februari 2013 Denpasar:Puslit L H Lemlit UNUD.

[10] Sumarta, I.KI. 2001. Language and Identity between Globalization and Illiteracy. Bali Living in Two Worlds. Base Museum der Kuturen and Verflag Schabe \& AG53.

[11] Rasna, I Wayan and Binawati Ni Wayan S. 2012. Pemertahan Leksikal Tamanan Obat Traditional untuk Penyakit Anak pada Komunitas Remaja di Bali : Kajian Semantik Ekolinguistik in Jurnal Bunga Lestari Volume 12 Nomor 1, Februari 2012. Denpasar: Puslit Lingkungan Hidup Lemlit Unud.

[12] Sujarwo, Wawan et al. 2014. Cultural Erosion of Balinese Indigeneous Knowledge of Food and Nutriceutical Plants in Journal Economic Botany Vollume 68 Number 14.New York: The Society for Economic Botany

13] Putra, S.W. 1994. In Situ Conservation in Asia. The Kebun Raya Bogor Conference Proceedings. Kebun Raya Indonesia. Bogor: LIPI . p. $8-17$

[14] Trubus Infokit. N.d. Herbal Indonesia Berkhasiat Bukti Ilmiah dan Cara Racik.Bogor: PT Trubus Swadaya.

[15] Tirtha, Pande Ketut. 19871 Tanaman Obat dalalm Lontar Usadha. Denpasar: Proyek Pengadaan Pengembangan dan Pengawasan Obat dan Makanan Dinas Kesahatan Provinsi Bali.

[16] Sukandar, Elin Yulinah, 2004. Trend dan Paradigma Dunia Farmasi :Industri- Klinik - Teknologi Kesehatan Bandung:Departmen Farmasi, FMIPA, ITB.

[17] Tantra Dewa Komang and Rasna, I Wayan. 2016. Implementasi Usadha sebagai Kearifan Lokal Bali dalam Meningatkan Minat Masyarakat dan Wisatawan Mengonsumsi Kuliner Lokal untuk Meningkatkan Ekonomi Kreatif Masyarakat Bali.

[18] Foster, George. M. and Anderson Barbara Gallatin.1986. Medical Anthropology .Translated by Priyanti Pakan Suryadarma dan Meutia F. Hatta Swasono. Jakarta UI Press.

[19] Hariana, Arief. 2009. Tumbuhan Obat dan Khasiatnya Seri 2.Bogor: Penebar Swadaya

[20] Dalumartha,Setiawan.2008.Atlas Tumbuhan Obat Indonesia Jilid 5 Jakarta: Pustaka Buda.

[21] Mun'im, Abdul dan Hanani Endang. 2011. Fitoterapi Dasar. Jakarta: Dian Rakyat

[22] Septian, Entin. 2009. Apotek Hidup Rempah -Rempah Tanaman Hias dan Tanaman Liar. Bandung: CV Yrama Widya

[23] Sejati,NIP. 2002. Formulasi, Karakterisasi Kimia, dan Uji Aktivitas Antioksida dan Produk Minuman Traditional Berbasis Kunyit Asam Jawa.Bogor: Laporan Peneltian.

[24] Nuraini, Ini Nuris. 2014. Aneka Daun Berkhasiat Obat. Yogyakarta: Gava Media

[25] Elshabrarma. 2013. Dahsyatnya Daun Obat sepanjang Masa.Yogyakara: Cemerlang Publishing

[26] Khalil, Munawar. 2016. Beras Mengatasi Berbagai Penyakit Degeneratif Seperti Diabetes, Kanker dan Jantung Koroner. Jakarta: Andi Offset

[27] Tengah, I Gusti Putu, et al.1995. Studi Inventarisasi Determinasi dan Cara Penggunaan Tanaman Obat pada Lontar Usadha di Bali.

[28] Untung, Onny. N.d. Trubus Infokit Herbal Indonesia Berkhasiat Bukti Ilmiah \& Cara Racik.Bogor: PT Trubus Swadaya

[29] Woersley ,P.J. 1972. Babad Buleleng: A Balinese Dynastic Chronicle. Nyhoff. The Haque

[30] Hobart, M. 1990. ThePatience of Plants; A Noteon Agency in Bali. Rev.Indonesia Malays.Stud (Sepc.Bali Ed 24(2).;85 -140

[31] Sujarwo et al.2005. Ethnobotanical Study of Loloh: Traditional Herbal Drinks from Bali (Indonesia) in Journal of Ethnopharmacology 169 (2015) $34-48$.

[32] Fadiati, Ani. 2012. Mengelola Jasa Boga yang Sukses. Bandung: Rosda Karya 
[33] Barbara,F, Okum, Jane Fried, Marcia L - Okun.1999. Understanding Diversity: a learning

[34] William Wongso \& Walsh Mansion, Chef., 2015 [online] available at: http://www,embassyofIndonesia.org/wordpress/wpconten/uploads/2015/05/PR-Pasport-DC-fin.ptdf [assessed22 Aug.2016]

[35] Atmojo, J,Marsum Widjojo. 2004. Bar, Minuman dan Pelayanannya.Yogyakarta: CVAndi Offset.

[36] Sudarma Momon. 2009. Sosiologi Kesehatan.Jakarta: Salemba Medika

[37] Citra,I putu Anand. 2016. Pemetaan Potensi Ekowisata Wilayah Pesisir di Kabupaen Buleleng in Jurnal Ilmu Sosial dan Humaniora. Volume 5,Nomor 1 April 2016.

[38] Sukerti, Ni Wayan et al. 2016. Revitalisasi Makanan Traditionsional Buleleng sebagai Upaya Pelestarian Seni Kuliner Bali in Jurnal Ilmu Sosial \& Humaniora Volume 5, Nomor 1 April 2016

[39] Arida, I Nyoman Sukma, 2009. Meretas Jalan Ekowisata Bali. Denpasar: Udayana Univesity Press

[40] Hermawati, n.d. .Potensi Buah Pare Sebagai Herbal Antifertilitas. Bandung: Jurusan Pendidikan Biologi FPMIPA

[41] Sujarwo, Wawan et al., 2016. Ethnobotanical Use of neem (Azadirachta idica.Juss; Meilaceae) leaves in Bali (Indonesia) and the ground and phytochemical properties with Historical bakground and phytochemical properties in Joural Ethnopharmacology 189 (2016) $189-193$

[42] Delima, et al. 2012.Gambaran Praktik Penggunaan Jamu Oleh Dokter di Enam Provinsi di Indonesia dalam Buletin Penelitian Kesehatan, Volume 40, No3, 2021: 109- 122.

[43] Defang. L.et al..200\15.Effect of San huang wuji Powder, anti rhematic drugs,and ginger - partitioned accupoint stimulation on the Treatment of Rheumatoid Arthritis with Peptic Randomized Controlled Study .Journal of Traditional Chinese Medicine 35 (3):273- 280

[44] Chainani, N. 2003.Safety and anti-inflammatory Activity of Curcuein: A component of Turmeric (Curcuma Longa). The Journal of Alternative and Complementary Medicine 9 (1): 161;168

[45] Devaraj, S. Ismail et al.2014.Investigating of Antioxidant and Hepato protective activity of Standardized Curcuma Xanthorihiza Rhizome in Carbon Tetrachoride - Induced Hepatic Damaged Rats. The Scientific Journal 2014: 1-8

[46] Rukmana, H Rahmat and Yudirahman H Herdi.2016.Budi Daya \& Pasca Panen Tanaman Obat Unggulan. Yogyakarta: Lily Publisher.

[47] Pujimulyani.,Dwiyati. Prof.Dr. Ihj.MP. 2016. Kunir Putih. Bekasi: Gramata Publishing 